\title{
Impacts of Blending Feed Stock Generated Biodiesel on Performance and Emission Parameters of Diesel Engine-Review
}

\author{
${ }^{1}$ Monika Vyas, ${ }^{2}$ V. D. Sonara \\ ${ }^{1,2}$ Assistant Prof. Mechanical, LDCE Ahmedabad, India. \\ 1'mkvyas@Idce.ac.in, ${ }^{2}$ sonaravimal@gmail.com
}

\begin{abstract}
Alternative fuels are in demand to overcome limitations of fossil fuels since decades. Indian Standards of biodiesel exists and its wide application is appealed and a National Policy on Bio fuels was implemented by Ministry of New and Renewable Energy. This Paper presents a review of biodiesel, Indian standards and difference of ASTM/EN for biodiesel. Biodiesel and its different blend fuelled in Diesel engine exhibit different engine performance and exhaust gas emission characteristics. Various performance parameters affects compression ignition diesel engine (DI-CI) performance, list includes fuel injection pressure, fuel quantity injected and injection timing, shape of combustion chamber, position and size of injection nozzle hole, fuel spray pattern, etc. Few paramount factors governing DI-CI engine includes various types of biodiesel and its blending with diesel engine. Types of blending are namely mahua, jatropha, karanja, waste cooking oil etc. Authors have blended them with varying percentage with varying fuel injection pressure at different loads. Few have also used alumina as nano additives in mahua biodiesel (B25100Al203) to check it effects on performance parameters as well as on emission characteristics. Effect of blending with Karanja, Jatropha, Neem , mahua etc as biodiesel with inclusion of alumina as nano additives are reviewed for related performance parameters (i.e. brake thermal efficiency (BTE), brake specific fuel consumption (BSFC)) and emission characteristics (i.e. CO, HC, NOx) in exhaust gas emission in different conditions for DI-CI Engine performance.
\end{abstract}

Key words: Diesel Engine (DI), Blends of biodiesel, Nano additives, Performance characteristics, Exhaust gas Emission.

\section{INTRODUCTION}

Diesel engines are the primary power plant of vehicles used in heavy duty applications. This includes buses, large trucks and mining equipment. Furthermore, worldwide diesel engines are increasing in light duty applications [5]. Diesel engines can be fuelled with pure diesel or with various biodiesel blends. Government of India has recently formulated a biofuel policy with an aim to supplement about $10 \%$ of diesel consumption through biodiesel by the end of 2016-2017 [3]. From this important step of Government, one can understand the importance of biodiesel and its blending for our diesel fuel vehicle which covers most of the portion of our transportation sector and hence there is a need to enhance the biodiesel production [3]. Further, over recent past year's stringent emissions legislations are imposed word wide on NOx, smoke and particulate emitted from diesel engine [3]. In this section, we have included biodiesel and its standards; need to opt for biodiesel and advantages due to blending of biodiesel.

In order to promote bio fuels in India,[2] The Union Cabinet, has approved National Policy on Biofuels in 2018 made by Ministry of New and Renewable Energy during the year 2009. Stating one of the salient features is "The Policy categorizes biofuels as "Basic Biofuels" viz. First Generation (1G) bioethanol \& biodiesel and "Advanced Biofuels" - Second Generation (2G) ethanol, Municipal Solid Waste (MSW) to drop-in fuels, Third Generation (3G) biofuels, bio-CNG etc. to enable extension of appropriate financial and fiscal incentives under each category'. This Policy encourages setting up of supply chain mechanisms for biodiesel production from nonedible oil seeds, used Cooking Oil, short gestation crops [2].

Biodiesel is a bio-based fuel that is usually derived from vegetable oils such as palm oil, soybean oil, canola oil etc. The first national biodiesel specification in the USA was ASTM standard D6751, "Standard Specification for Biodiesel Fuel (B100) Blend Stock for Distillate Fuels", adopted in 2002 [1], [3].EN14214 is a standard published by the European Committee for Standardization that describes the requirements and test methods for FAME [Fatty Acid Methyl Esters (FAME)] the most common type of biodiesel. Indian Standard 15607:2005 is mainly based on the European specification EN14214, with some 
specifications taken from the USA specification ASTM standard D6751. It contains the requirement and the method used for testing of Biodiesel (B100) (FAME) [1], [3].

Properties of biodiesel are defined as a fatty acid alkyl (methyl or ethyl) ester for use as blending component in diesel specified in the Indian Standard 15607:2005. There are also certain differences between the Indian standard and EN/ASTM specifications, in part reflecting the focus on different feed stocks (such as jatropha and pongamia) [3]. Specifications like: mono-, di- and tri-glycerides; poly unsaturated methyl ester; linolenic acid methyl ester; and low temperature properties (CP, CFPP, PP) are not part of this paper. Some parameters are only to be reported: $\mathrm{Na}$, $\mathrm{K}, \mathrm{Ca}, \mathrm{Mg}$ and iodine value. The specification includes limits on both methanol and ethanol [2]. Biodiesel consists of fatty acid alkyl esters which are obtained through transesterification reaction of vegetable oils and animal fats with an alcohol (most commonly methanol or ethanol) in the presence of a suitable catalyst.

Term Biodiesel refers to mono alkyl methyl esters of vegetable oils like "rapeseed, soya bean, sunflower, jathropa cureas, karanja, palm stearin, etc [3]. Pure biodiesel B100 is the designation given to the type of fuel which consists of mono-alkyl esters of long chain fatty acids derived from vegetable oils or animal fats. It can be used as standalone for heating application and industrial engines; while it can also be used as a blended stock for diesel fuel. Blends are designated as "B" followed by a number indicating the percentage biodiesel. For example: B100 is pure biodiesel. B99 is $99 \%$ biodiesel, $1 \%$ petro diesel. B20 is $20 \%$ biodiesel and $80 \%$ diesel etc. Blended fuel consist of B6 to B20 as a percent volume, with the remainder being a light middle or middle distillate grade diesel fuel to meet the requirement of this specification. Small amounts of hydrocarbons or non-hydrocarbon additives can be used to improve performance and emission control [3].

Moving to advantages of biodiesel blending on performance and emission characteristics of diesel engines it depends on various factors like fuel injection pressure, fuel quantity injected and injection timing, shape of combustion chamber, position and size of injection nozzle hole, fuel spray pattern, air swirl etc [5]. Even though biodiesel cannot entirely replace diesel fuel, advantages it offers are [5], [6]. (1) It is non-toxic with higher biodegradability than diesel fuel (2) An oxygenated fuel with approximately $10-12 \%$ oxygen by mass in the molecular structure. Leads to better combustion efficiency with less harmful emissions such as particulate matter (PM), unburned or half-burned hydrocarbons (HC) and carbon monoxide (CO) (3) It can be produced by using domestic renewable feedstock.(4) Biodiesel has higher flash point temperature than diesel fuel, which makes it safer to transport and handle (5) It can be completely miscible with diesel fuel, allowing the blending of these two fuels in any proportion. (6) The fuel properties of biodiesel are compared to petroleum diesel fuel, biodiesel has higher viscosity, density, pour point, flash point and cetane number, non aromatic compound [6]. Disadvantage of blending is lower heat of combustion and volatility, and higher viscosity and cloud point temperature. [4]

\section{REVIEWS}

Number of research papers and studies has been conducted on blending of biodiesel and related performance and emission characteristics study or experimental evaluation. Number of reviews has been taken as follows to complete the present study

Experiments were performed on 4 Stroke diesel engine rated 5.2 KW operated at $1500 \mathrm{rpm}$ with increasing injection pressures in three steps from 200, 220 bar and 240 bar at different load conditions .Blend was formed with alumina nano particles as additives with Mahua biodiesel. Blend B25 (75\% Diesel + 25\% Mahua biodiesel) and the Alumina nano particles were added in the proportion of $100 \mathrm{ppm}$ by mass fraction $\left(\mathrm{B} 25100 \mathrm{Al}_{2} \mathrm{O}_{3}\right)$. An effect of injection pressure and nano particles on PEC was studied. Results of $\mathrm{B} 25100 \mathrm{Al}_{2} \mathrm{O}_{3}$ was analyzed with diesel at 200 bar. Thus $\left(\mathrm{B} 25100 \mathrm{Al}_{2} \mathrm{O}_{3}\right.$ ) was formed and properties were mentioned. Engine Performance and Emissions for $\mathrm{B} 25100 \mathrm{Al}_{2} \mathrm{O}_{3}$ biodiesel blend at fuel injection pressures 200, 220 and 240 bar with different load conditions experiments were performed [7]. With increasing load and

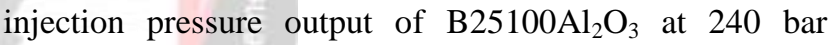
pressure as compared in percentage with diesel at 200 bars was evaluated and stated with reasons in terms of Performance (BTE and BSFC) and emissions. With this experiment, author found that BTE was increasing with load and pressure. It increased about $12 \%$ (due to more atomization and improved combustion.) BSFC was decreasing with an increase in the load respectively, 7.8\% decrease was noted. (As due to increased fuel injection pressure spray cone angle and penetration length increases) Results of above experiment are: $\mathrm{CO}$ emission is reduced, almost $25 \%$ (due to higher thermal conductivity of nano particles and proper mixing of air fuel particles resulting in good combustion) HC's are reduced almost 29.4\% (nano additives in biodiesel and deeper penetration achieved due to complete combustion with fine fuel spray) NOx has increased at all injection pressures and blends [7], [8]. There is about $9.36 \%$ increased. $\left(\mathrm{N}_{2}\right.$ reacts more with oxygen and produces more NOX emissions at high temperature) Smoke: It is observed about $24.48 \%$ decreases in smoke opacity (achieved due to better atomization so reduced smoke at high injection pressures.)

Author has come to the conclusion that, increased injection pressure with addition of nano particles in biodiesel increased BTE and reduced BSFC. In exhaust gas emission $\mathrm{HC}, \mathrm{CO}$, smoke opacity emissions were reduced 
whereas NOx percentage was increased as compared to $\mathrm{B} 25100 \mathrm{Al}_{2} \mathrm{O}_{3}$ at 240 bar pressure with diesel at 200 bar. Thus $\mathrm{B} 25100 \mathrm{Al}_{2} \mathrm{O}_{3}$ at 240 bar pressure was satisfactory. It can be concluded that injection pressure of fuel and nano particles composition influenced the performance and exhaust gas emission. More atomization of the fuel takes place with increasing the fuel injection pressure, which influences the quality of combustion and cylinder pressure. In another study of blends (diesel with Jatropha and Karanja oil) were prepared at $20 \%$ volume to the diesel.(JD20 and KD20 respectively) [9]. It was tested as alternative fuels in single cylinder water-cooled, DI-CI engine at the rated speed of $1500 \mathrm{rpm}$. Taguchi Method of Optimization was opted to determine number of trials required to perform. Higher ignition delay for JD 20 and KD 20 blend than diesel and the trend was maintained decreasing uniformly with respect to the increasing loads of engine operation. The reason is due to the $20 \%$ blend of vegetable oil with diesel that reasonably influences combustion starting point. Thermal efficiency was focused upon for pure diesel and blends of Jatropha and karanja. The combustion pattern also reveals the slow burning characteristics of vegetable oils and this study indicates that the blended biofuels have combustion characteristics that are similar to regular diesel fuels.

Analysis says Jatropha oil showed better results in terms of engine performance and emissions at high loads compared to karanja oil. Jatropha and Karanja oils were chosen for investigation $20 \%$ blend, acceptable thermal efficiencies of the engine were attained with fuel blends upto $50 \%$ volume.

Results states that the performance of the engine in terms of thermal efficiency at full load for pure diesel was $30 \%$. For JD20 and KD is $29 \%$ and $28.6 \%$, respectively. Thus can be concluded that blended biodiesel JD20 and KD20 are performing closer to diesel.

Another author have carried out engine tests on a diesel power generator model CAT3412 four-stroke, supercharged diesel engine at rated speed of $1530 \mathrm{rpm}$ [12]. Increasing load (\%) as 25, 50, 75 and 100 operated with biodiesel from waste cooking oil and diesel fuel blends (B0, B20, B50, B80 and B100) was experimented. Biodiesel in most cases was prepared by adopting transesterification process [8]. Biodiesel from waste vegetable cooking oil was produced by a transesterification process catalyzed by $\mathrm{KOH}$ Alkali catalyst and methanol as alcohol was used. Performance characteristics where focused. Analysis on the engine performance (brake power, BSFC, BTE were evaluated)

Analysis revealed Maximum brake power appeared 130 $\mathrm{kW}$ for the fuel blend included $50 \%$ biodiesel at full engine and minimum $24.8 \mathrm{~kW}$ at $25 \%$ engine load for B100. Relatively at higher engine loads biodiesel has beneficial effect as an oxygenated fuel leading to complete combustion, which means increased brake power[10],
[12]. Also the minimum brake specific fuel consumption (210 (gr/Kw.hr)) at full engine load for the fuel blend included $20 \%$ biodiesel. BTE of the engine is higher for B20 and B50 than that of B0. In all cases, brake thermal efficiency has the tendency to increase with increase in applied load.

Results leads to Performance and environmentally friendly emissions observed for B20 and B50 with vegetable cooking oil blends so can be used in unmodified diesel engines. B20 gives the best brake thermal efficiency of engine. Exhaust gas temperatures of biodiesel is decreased on average $8.2 \%$ than diesel fuel.

\section{CONCLUSION}

From above facts and findings we can conclude that, there is an effect of an injection pressure. Higher injection pressure yields more atomization and quality combustion in general which results in high temperature inside the combustion chamber for biodiesel blends in diesel engine. Injection pressure of fuel and nano particles composition affects the performance and emission of an engine $\mathrm{B} 25100 \mathrm{Al}_{2} \mathrm{O}_{3}$ at 240 bar pressure was more satisfactory as compared to diesel at 200 bar. Due to nano additives in biodiesel reduction in $\mathrm{HC}$ emissions and deeper penetration and complete combustion achieved due to fine fuel spray. Exhaust gas temperatures are lower in biodiesel blends as compared to diesel fuel for all of the engine loads. For waste cooking oil biodiesel blend B20 to B50 can be preferable whereas B20 gives maximum thermal efficiency. Brake thermal efficiency for Jatropha diesel blend (JD 20) and Karanja blend (KD20) is closer to diesel engine, additionally Jatropha blend is slightly better as compared to Karanja biodiesel. In blend exhaust emission $\mathrm{HC}$ and $\mathrm{CO}$ decreased as compared to diesel. NOx increased in all blends of biodiesel, the reason is $\mathrm{N}_{2}$ reacts with oxygen and produce more Nox due to high temperature as a result of high temperature in combustion chamber.

\section{REFRENCES}

[1] Alternate fuel data centre and online https://dieselnet.com/standards/us/fuel_biodiesel.php

$[2$ Official

Press release https://pib.gov.in/Pressreleaseshare.aspx?PRID=1532265 (press release), 2018

[3]BIS, bdai.org Biodiesel (B100)- Fatty Acid Methyl Esters (Fame) -specification, BIS (May 2016)

[4] Bilgin Atilla, Gulum Mert "Regression models for predicting some important fuel properties of corn oil biodiesel-diesel fuel blends", 8th International Exergy, Energy and Environment Symposium. (May 2016)

[5] K. Kannan and M. Udayakumar, "Experimental study of the effect of fuel injection pressure on diesel engine 
performance and emission" ARPN journal of Engineering and Applied Sciences vol (May 2010)

[6] Suat Sarıdemir, Ali Etem Gürel, Ümit Ağbulut $\square$, Faruk Bakan, "Investigating the role of fuel injection pressure change on performance characteristics of a DI-CI engine fuelled with methyl ester" 117634 Fuel 271 ( Feb 2020)

[7] G. Jamuna Rani, Dr.Y.V. HanumanthaRao, Dr.B. Balakrishna, "Investigation of fuel injection impact on CI engine performance and emissions using biodiesel blend with alumina nano additives.", (IJMET) Volume 9, Issue 6, June 2018, pp. 922-928 (2018)

[8] Bharat Aher1, BhushankumarManmode. A Review of Performance and Emission Studies in CI Engine Using Biodiesel Obtained from Mixed Feedstock's, 1st National Conference On Recent Innovations in Mechanical Engineering (NCRIME-2018, IOSR Journal of Mechanical and Civil Engineering (IOSR-JMCE), e- ISSN: 22781684,p-ISSN: 2320-334X PP. 45-48

[9] B. Deepanraj, M. Srinivas, N. Arun, G. Sankaranarayanan \& P. Abdul Salam "Comparison of Jatropha and Karanja Biofuels on their Combustion Characteristics" International Journal of Green Energy, DOI: 10.1080/15435075.2017.1328420 (May 2017)

[10] Praveen A. Harari, Akshatha D. S, Manavendra. G "Effect of injection pressure and nozzle hole diameter on combustion parameters of CI engine fuelled with b20 neem blend", International Journal of Innovative Research in Science,Engineering and Technology Vol. 4, Issue 5, (May 2015)

[11] Jian Wu1, Lili Zhu1, Zhancheng Wang, Bin Xu1, and Hongming Wang,"Experimental Study of the Spray Characteristics of n-Butanol/ Diesel Blends, Advanced Materials Research Vols 960-961 (2014) pp 1394-1399

[12] Alireza Shirneshan, Amin Nedayali "Investigation of the effects of biodiesel-diesel fuel blends on the performance and emission characteristics of a diesel engine.” Jurnal Teknologi(science and Engineering) 78:6 (2016) pg 169-177. 